\title{
Housing Outcomes in Turkey: How Do Middle-Income Households Fare?
}

\author{
Samantha Friedman* \\ Associate Professor of Sociology \\ University at Albany, SUNY \\ Department of Sociology \\ 1400 Washington Avenue \\ Albany, New York 12222 \\ USA \\ Aysenur Kurtulus \\ Doctoral Student \\ University at Albany, SUNY \\ Department of Sociology \\ 1400 Washington Avenue \\ Albany, New York 12222 \\ USA \\ Ismet Koc \\ Professor of Demography \\ Hacettepe Institute of Population Studies \\ Hacettepe University \\ Beytepe Campus \\ Anakara, Turkey
}

January 4, 2020

*Direct correspondence to Samantha Friedman, Department of Sociology, University at Albany, SUNY, 348 Arts and Sciences Building, 1400 Washington Avenue, Albany, NY 12222 (samfriedman@albany.edu); phone (518-442-5458); fax (518-442-4936). We thank Professor Oguz Isik for his helpful feedback. This work was supported by a 2014-2015 Fulbright U.S. Scholar Research Fellowship. 


\title{
Housing Outcomes in Turkey: How Do Middle-Income Households Fare?
}

\begin{abstract}
Despite the doubling in size of the middle class and the significant housing increase in Turkey, little research has examined housing outcomes of middleincome households, particularly relative to affluent households. The housing increase and 2007 Mortgage Law could have reduced housing differences between middle-income and affluent households, but the rise in gated communities could have increased these differences. Using data from Turkey's 2012 Household and Budget Survey, we find that middle-income households are significantly less likely than affluent households to own their homes and live in larger homes, and among owner-occupiers, in homes of higher value. Less pronounced differences are found in their residence in newer homes. Fewer differences in housing outcomes exist between middle- and lower-income households, particularly among owner-occupiers. These results suggest that the most affluent households, rather than the poorest households, are likely isolating themselves from other households, thereby affecting the future well-being of middle-income households.

Keywords: Turkey, Housing Stratification, Middle-class

Word Count (including title page, references, and tables): 11,065
\end{abstract}




\section{Introduction}

By 2020 , for the first time in history, the middle class will comprise the majority of the global population (Kharas 2017). Much of the expansion of this segment of the population is due to the rising numbers of households in the middle class in Asia, particularly in China and India (Kharas 2017). But Turkey has also experienced significant growth in its middle-class population. In less than a decade, between 2002 and 2011, the share of the population in the middle class doubled in size from about $21 \%$ to $42 \%$ (The World Bank 2014). Indeed, out of 19 OECD countries, Turkey was only one of two countries whose growth in median income, taken to be an indicator of middle-income growth, was higher in the last decade than in previous decades (OECD 2019).

As in other emerging markets, since 2000 , Turkey has experienced significant economic growth. Its GDP levels more than tripled from $\$ 273$ billion USD in 2002 to $\$ 864$ billion USD in 2016 (The World Bank Data 2018). Turkey became the $16^{\text {th }}$ largest economy in the world and $6^{\text {th }}$ largest in Europe (Republic of Turkey Prime Ministry 2013). At the same time, Turkey's housing market has expanded significantly. Between 1990 and 2012, the number of housing units completed via new construction was about 6.7 million, which could accommodate about 23.5 million Turks, and the actual increase in Turkish population was 19.2 million (Turel and Koc 2015: 62). Thus, the amount population that could be accommodated by the new housing construction exceeded the actual increase in total population by $22 \%$ (see also Sarioglu-Erdogdu 2010a, Figure 2), thereby 
providing the Turkish population with a wide range of housing choices (Turel and Koc 2015: 62). In addition, since 2007, a mortgage-finance system has been in place, which has significantly expanded housing credit and made it easier for households to purchase housing in this expanding market (Sarioglu-Erdogdu 2014).

Given the increases in the middle-class segment of the Turkish population, the significant growth in newly constructed housing, and the fact that housing is a main source of wealth for Turks (Ceritoglu 2019), it is surprising that little research, to our knowledge, has explicitly examined the housing outcomes of middle-income households, relative to their lower- and upper-income counterparts, in this society. The very limited research on this topic focuses on homeownership by income groups. Coskun (2016) reports that the homeownership rates in 2013 for low, middle, and upper income groups were $59.3 \%, 56.3 \%$, and $65.9 \%$, respectively, revealing that lower-class households had higher homeownership rates than middle-income households. However, this study is descriptive in nature. Another study examines whether housing income is a key determinant of homeownership, second homeownership, and housing debt, controlling for other relevant factors, but the focus is not explicitly on middle-income households (Ceritoglu 2019). This latter study finds that higherincome groups are significantly more likely to own their homes, own second homes, and have housing debt than the lowest-income group. 
The purpose of our paper is to build upon the limited housing literature in Turkey and examine the nature of income-based disparities in homeownership as well as other housing outcomes. More specifically, using data from the 2012 Turkish Household and Budget Survey (HBS), this study seeks to fulfill the following objectives: 1) document and compare the extent to which incomebased disparities exist in residence in owner-occupied housing, unit size, access to newer homes, and for owner occupiers, examine disparities in unit size, access to newer homes, and housing value); 2) document income-group differences in socioeconomic characteristics, demographic factors and other residential characteristics related to housing outcomes that need to be controlled; and 3) examine whether disparities in housing outcomes persist with controls for such variables, overall and among owner occupiers. Our study seeks to provide a broader portrait of the housing attainment in Turkey, particularly for the growing, middle-income segment than has been available thus far in the literature.

\section{Background}

Housing is important in terms of its use and exchange values (Logan and Molotch 1987). In considering its use value, households consume housing and as such, it often reflects household tastes, lifestyle preferences, and the resources needed to fulfill such residential expectations. From an exchange value, housing is viewed through its ability to garner wealth for households. It is likely that significant income-based disparities exist in people's consumption of 
housing, in terms of their access to homeownership and larger and newer homes. At the same time, it is likely that income disparities exist for owners, in terms of housing value, reflecting the variation in exchange values that households are able to accrue from their homes. However, in both instances, less clear is the nature of these differences. While it is likely that affluent households are more likely than poorer households to own their homes and live in larger, newer, and more expensive homes, controlling for relevant factors, it is less clear where middle-income households fall on this continuum.

There are several unique features of the contemporary housing market in Turkey that could potentially minimize the differences in housing outcomes between middle-income and affluent households. Specifically, the following three aspects of the housing market are relevant in this regard: 1) the 2007 Mortgage Law; 2) the increase in housing stock produced by Turkey's Housing Development Administration (HDA); and 3) the lack of differences in housing quality found between rental- and owner-occupied housing (Sarioglu-Erdogdu $2014,2015)$. All of these factors, we discuss below, have broadened the opportunities of middle-income households to live in higher-quality housing than may have been the case before the 2000s in Turkey. In addition, these factors have likely afforded middle-income households similar use values in access to housing as well as exchange values, relative to upper-income households. 
Characteristics Minimizing Middle-Income and Affluent Housing Disparities

In 2007, Turkey enacted the Mortgage Law, which allowed banks and other lending institutions to provide financing for households to purchase property (Sarioglu-Erdogdu 2014). Prior to 2007, there had been no mortgage financing system available in Turkey (Sari and Khurami 2018; Sarioglu-Erdogdu 2014). Unique to the Turkish market, however, is the fact that even in the absence of the mortgage system, home ownership rates have been high; between 1987 and 2003, at least two-thirds of the Turkish population owned their homes (Sarioglu-Erdogdu 2010a). Because of very high levels of inflation in Turkey and the absence of government intervention into the housing market, it was not until 2007 that such a financing system could be put into place (SariogluErdogdu 2014). However, the law requires a downpayment of $20-25 \%$ of the home purchase price and generally a 10-year loan term, making it difficult for low-income homebuyers to acquire these loans (Sari and Khurami 2018). Thus, the segments of Turkish society that most likely benefit from this finance system are middle- and upper-income households.

The new mortgage system appears to be having a positive impact on the Turkish housing market. Between 2007 and 2013, there was more than a fourfold increase in mortgage loan volume, rising from 20 bn TL to just over 90 bn TL (Coskun 2016). In addition, in the 2000s, increases in housing production were parallel to the upward trends in mortgage volume, which was not the case in earlier decades (Turel and Koc 2015). As suspected, low-income households 
do not seem to be using these loans to buy housing as much as middle- and upper-income segments. In 2014, of those households characterized as owners with debt or a mortgage, only $12.3 \%$ were from the lowest and low income segments, with the rest being composed of middle- and upper-income segments (Sari and Khurmani 2018).

The use of this system has likely broadened the range of housing options for the middle-class, relative to affluent households. Recent research on gated communities in Ankara and Istanbul suggests that middle-class households increasingly aspire to live in these exclusive, residential communities that have been traditionally occupied by affluent Turks and implies that the financing offered by the mortgage system could assist middle-class households to realize these residential preferences (Erkip 2010; Genis 2007; Guzey 2014; Kurtulus 2011). According to Kurtulus (2011), in recent years, middle-class Turks have enjoyed easier access to financial credit, which has boosted their social status and expanded their housing options to include gated communities in peripheral areas of Istanbul. Owning a home in gated communities is symbolic of an "ideal form of lifestyle for the newly rising classes to show off their economic and cultural capital” (Kurtulus 2011: 53). The marketing of gated communities by the real estate sector in Turkey's major cities is a prominent force in reinforcing and perpetuating the residential preferences of middle- and upper-income households and ultimately in shaping the urban landscape in Turkey (Guzey 2014). 
Another factor that could limit the differences in housing outcomes between middle-income and affluent households relates to the role that Turkey's Housing Development Administration (HDA), also known as TOKI, played in increasing owner-occupied housing stock since the early 2000s (Coskun 2016; Ozdemir 2011; Sarioglu-Erdogdu 2014; Turel and Koc 2015). Historically, the HDA had a very limited role in the provision of housing in Turkey, and instead private developers have been largely responsible for housing production, which is unique to the Turkish housing market (Ozdemir 2011; Sarioglu-Erdogdu 2010a). However, after 2002, the Office of the Prime Minister became responsible for administering the HDA, and 64.5 million square meters of public lands were transferred to the HDA, transforming the HDA into a housing provider and more powerful agent of housing development than local authorities (Ozdemir 2011: 1106). Since 2004, the HDA been a primary force in the "regeneration of squatter housing areas" or areas occupied primarily by gecekondus, which has involved the destruction of existing shanties and development of new housing stock by the HDA (Ozdemir 2011: 1106). The HDA has completed more than 780,000 housing units in Turkey, which are all comprised of owner-occupied housing, since 2003 (Sari and Khurami 2018).

Although the HDA implements a "social housing program" (TOKI 2019), the main beneficiaries of the owner-occupied housing produced by the HDA have been upper-low income and middle-income households (Ozdemir 2011; Sari and Khurami 2018; Sarioglu-Erdogdu 2014; Turel and Koc 2015). According to Sari 
and Khurami (2016: 7), "20.6\% of all affordable housing projects realized by TOKI are for the poor households (lowest $20-40 \%$ income group as defined by the TOKI), whereas $43.1 \%$ of them are for low to middle-income households," which includes those in at least the $40^{\text {th }}$ percentile group and is at the lower-end of the middle class. Indeed Ozdemir (2011: 1111) finds evidence suggesting that $90 \%$ of the owner-occupied housing produced by TOKI became occupied by middle- and upper-income households.

Affluent households benefit from the HDA's "revenue-sharing approach," which allows private builders to construct high-end housing on HDA-owned land specifically for upper-income households (Palancioglu and Cete 2014). The income generated from the sales of these units is shared between the private builders and the HDA. According to Palancioglu and Cete (2014: 131), in 2014, $15 \%$ of the housing produced by the HDA was this type, and since $2004,30 \%$ of the HDA's income was produced by these upper-end housing units. Given the recency of construction of HDA, owner-occupied housing and its widespread availability to middle- and upper-income housing, it's likely that the HDA has minimized differences in housing outcomes between these two groups of households within the Turkish housing market.

A final factor that could minimize the differences in the housing quality outcomes between middle- and upper-income households is the fact that rentaland owner-occupied housing stock share similar features, contrary to the pattern found in most Western housing markets (Sarioglu-Erdogdu 2015). In large part, 
this unique aspect of the Turkish housing market can be attributed to the population growth and rapid urbanization that both took place in Turkey during the $20^{\text {th }}$ century, whereby the majority of country's population shifted from living in rural areas to urban areas (Sarioglu-Erdogdu 2010a). With the absence in the provision of socialized housing, the Turkish government enacted the Law on Flat Ownership in 1965 to assist with the emerging crisis of housing the increased population in urban areas (Sarioglu-Erdogdu 2010a). The law allowed individual homeowners to rent their homes, thereby establishing a private rental market based upon "mom and pop" owners (Sarioglu-Erdogdu 2010a). Some owners occupied their homes and others rented their homes, thereby minimizing differences in the housing outcomes of owner- and renter-occupiers.

With significant inflation rates in Turkey in the 1980s and 1990s and the passage of this law, housing become a significant investment for individual families in Turkey. In the 1990s, private developers responded to this demand for investment by significantly expanding the housing stock (Sarioglu-Erdogdu 2010a). For example, between 1993 and 1995, the annual number of housing units produced was at least half a million (Sarioglu-Erdogdu 2010a). The housing stock produced by private developers during this period was predominated by three-room dwellings, thereby minimizing differences in size between owner-occupied and renter-occupied housing (Sarioglu-Erdogdu 2010b). 
Indeed, according to a study done in Ankara, both types of housing are similar in terms of their size and number of bedrooms and are neither type is geographically isolated (Sarioglu-Erdogdu 2015). Data from the Turkish Statistical Institute (2016) on occupancy permits reveal that $62 \%$ of all of the completed or partially completed residential buildings contained at least three dwelling units, and the average size of those dwellings was 147 square meters. Thus, the majority of the housing stock in Turkey, regardless of whether it is rental- or owner-occupied, is in apartment buildings. Although in urban areas in Turkey the homeownership rates of middle-income households are lower than those for more affluent households, it is likely that housing tenure differences do not necessarily translate into differences in housing conditions because of these similarities in rental- and owner-occupied housing stock.

\section{Characteristics Widening Middle-Income and Affluent Housing Disparities}

Despite the promise of the aforementioned factors in potentially reducing differences in housing outcomes between middle- and upper-income households, there are other factors that need to be considered that could have the opposite effect and widen differences between these groups, including income inequality, class-based, residential segregation, and variation in the exclusivity of gated communities in Turkey. As will be discussed below, these factors could potentially exacerbate differences by social class in the exchange value garnered by households from their housing. Because the wealth of Turks is inextricably linked to the value of their housing, these factors may have allowed affluent 
households to accrue greater gains in value than middle-income households and thereby occupy better quality homes than middle-income households.

Income inequality exists in Turkey, and in 2014, the Gini coefficient for Turkey was .393 , which was the fourth largest rate among OECD nations (OECD 2016). Examining the trends in income inequality over time reveals that for Turkey, these levels have been stagnant around a high level of .40 between 2005 to 2016 (Torul and Oztunali 2018). Wealth inequality in Turkey is even greater and has been growing over time, signifying a tightening control of wealth by the most affluent (Torul and Oztunali 2018). More specifically, the share of wealth in the top decile in Turkey grew from $66.7 \%$ in 2000 to $77.7 \%$ in 2014 , making Turkey the country with the second highest level of wealth inequality, behind Russia (Torul and Oztunali 2018: Table A.1).

Macrolevel income inequality often translates to the individual level in the form of inequalities in residential location. The increasing levels of wealth inequality in Turkey imply that affluent households likely have significantly better housing conditions than non-affluent households, including those in the middle class. Studies of residential segregation in Istanbul, Ankara, and Izmir consistently show that high-status groups are the most separated from the lowstatus groups, with middle-status groups residing between the two other groups (Atac 2017; Pinarcioglu and Isik 2009). High-status neighborhoods are generally found in the most desirable areas in these cities in terms of amenities and quality of life; in Istanbul and Izmir, these neighborhoods are located mostly in the 
coastal areas (Atac 2017). In other cities like Kayseri and Diyarbakir, high status neighborhoods are closer to the city centers because that is where the main functions of the city reside and therefore are the most desirable (Atac 2017). The low-status neighborhoods are in areas with the least amount of the amenities.

During the past two decades, the residential separation of affluent households from middle- and lower-class households has been facilitated by the rise in gated communities and the development of exclusive communities on the fringes of major cities like Istanbul and Ankara (Genis 2007; Guzey 2014). As mentioned above, in recent years, these communities have become more widespread in Turkey's major cities as well as more accessible to middle-income households (Genis 2007; Guzey 2014; Kurtulus 2011). However, there is variation in the exclusivity of gated communities, with some only catering to the very affluent households in the society and thereby allowing for the "concentration of wealth among high-income groups" (Genis 2007: 777).

In Istanbul, Kemer Country is one of the original gated communities in Turkey that has served as a protoype of "an exclusive and exclusionary elite localism" (Genis 2007: 780). Two factors have perpetuated its status as an elite residential enclave. First is its geography. Kemer Country is located on 3200 acres of forested land on the outskirts of Istanbul that is part of a national park (Genis 2007). The developers of Kemer Country consulted with "new urbanists" and designed the community to integrate housing with necessary amenities, like high-end restaurants and shops, to cater to the people living in the community so 
that it looks more like an edge city rather than just a gated community (Genis 2007). Second, and perhaps more importantly, there is an explicit screening process that determines whether residents can live in Kemer Country: "prospective residents have to undergo a strict application process that scrutinizes their occupational and educational background and their social and cultural capital in addition to their income level" (Genis 2007: 784). Both of these factors foster a separation of the very affluent households in Turkey from non-affluent households, thereby enhancing the use value of living in such communities and preserving the high levels of exchange values, which maintains the wealth of these households.

Our analysis seeks to explore income-based differences in housing outcomes in urban areas in Turkey. Given the above discussion, we will examine whether: 1) the outcomes for middle-income households are relatively similar to affluent households, due to changes in the housing market that have facilitated access to equivalent housing stock for these groups; or 2) the outcomes of middle-income households are drastically inferior to those of affluent households because of income inequality, residential segregation, and the rise in gated communities, which have potentially separated affluent households from their middle-income counterparts. We will also compare the housing outcomes of middle-income households to lower-income households.

First, we employ descriptive analyses to examine the nature and extent of differences in housing outcomes and socioeconomic, demographic, and other 
housing-unit characteristics between middle-class households and households of higher and lower income statuses. Then, using multivariate analyses, we examine whether income-based differences in housing outcomes persist when controlling for socioeconomic, demographic, and other housing-unit characteristics. The latter analyses are important because there are certain characteristics that vary between middle-income households and households of lower and higher income statuses that could also affect the housing outcomes. For example, there is likely a difference between middle-income households and other income households in the extent to which they own cars for personal use. Car ownership is indicative of the wealth that these households have, which would have an impact on the ability of middle-class households versus other households to own their homes and the quality of such homes. By not controlling for this factor and other variables that differ across income groups and could influence differences in housing outcomes, we risk overstating or understating income-based disparities in housing outcomes.

\section{Data and Methods}

The data for these analyses come from the 2012 HBS. These data are openly available at the Turkish Statistical Institute (http://www.turkstat.gov.tr/UstMenu.do?metod=bilgiTalebi). The HBS is a twostage stratified probability cluster sample of about 10,000 households, representative of 26 sub-regions in Turkey (Ucar 2015). The dataset is the only 
one in Turkey that contains data on the year that the housing unit was built, allowing for an analysis of the variation in the prevalence of recently constructed homes across income groups. In addition, the HBS has data on other housingrelated characteristics as well as housing value. For the purposes of our analysis, we restrict our analytical dataset to urban areas in Turkey where the majority of the population resides. In addition, we exclude rural areas because of the very different quality of housing in villages in these areas.

The 2012 HBS data are ideally suited for our study because they capture a period when the Turkish economy was the strongest in recent years and thus, disparities in housing outcomes between middle-income and affluent households would be at a minimum. The male unemployment rate of $7.6 \%$ was at its lowest level since 2000; after 2012, it climbed to $9.2 \%$ in 2015 and $9.5 \%$ in 2018 (The World Bank Data 2020a). Inflation in 2012 was also relatively low. The consumer price index, gauged against the value of the Turkish lira in 2010, was 116 in 2012, but it soared to 204 in 2018 (The World Bank Data 2020b). Finally, reliance on foreign credit was low as gauged by the share of foreign liabilities in total liabilities, which went from about $15 \%$ in 2012 to $22 \%$ in 2013 and has remained at that level since 2013 (The World Bank Group 2018).

We create several dependent variables to gauge housing outcomes. One key variable is housing tenure, and we create a dichotomous variable indicating whether the household occupying the home owns their home. We also calculate the average unit size in terms of square meters. As mentioned above, we create 
a dummy variable indicating whether the home is newly constructed. Included in the HBS data is a variable that includes eight categories of the year when permission was granted for the unit to be constructed, as reported by the household head or householder during the interview. We consider units that were built between 2001 and 2012 as newly constructed and those built before 2001 as older. Our final dependent variable, housing value, is just measured for owner occupiers and is in Turkish liras. We examine the average size of homes and the recency that homes were built among all households and among those in owner-occupied housing.

Our key independent variable is comprised of income groups categorized by household income. We created the categories based upon deciles and quintiles because we wanted to capture the extremes at the ends of the income distribution, like the affluent, while capturing broader groups in the middle of the distribution. Households whose income falls in the $40^{\text {th }}$ to $60^{\text {th }}$ percentile group (or the third quintile) comprise the reference group because they are the middle of the income distribution, and one of our main goals is to examine affluent households relative to middle-income households. There is no set definition for middle-income households, but the definition we adopt in this paper is similar to that used by Dwyer (2009) who also examines housing outcomes of middleincome households. The other income categories are as follows: 1) 0 to $10^{\text {th }}$ percentile; 2) $10^{\text {th }}$ to $20^{\text {th }}$ percentile; 3$) 20^{\text {th }}$ to $40^{\text {th }}$ percentile; 4) $60^{\text {th }}$ to $80^{\text {th }}$ percentile; 5) $80^{\text {th }}$ to $90^{\text {th }}$ percentile; and 6) $90^{\text {th }}$ to $100^{\text {th }}$ percentile. For each 
category, the income cutoff in the lower-bound percentile is included in the group, but the income cutoff of the upper-bound percentile is not included in order to create mutually exclusive categories. In the HBS data, households have unique income values, and the number of households by deciles/quintiles is virtually identical in the respective groups.

Our analysis also focuses on other variables that measure socioeconomic, demographic, and housing unit characteristics that could help to explain why income-group differences exist in housing outcomes in Turkey. Socioeconomic status is gauged by several variables. We create three dummy variables indicating whether the householder has: 1) a primary education or less (i.e., illiterate; literate but not completed school; primary school; primary education); 2) a secondary, high school, or vocational degree (i.e., secondary school; junior vocational high school; high school; senior vocational high school); or 3) at least some college education (reference) (i.e., 2-3 years of college; 4-year college or university; post graduate/PhD).

We measure socioeconomic status with two additional variables gauging employment status and car ownership. With respect to the former, we use the following three dummy variables indicating whether the householder is: 1) retired (i.e, retired or quit the job; elderly; disabled or unable to work); 2) in another labor force status (i.e., working part-time; looking for a job; continuing education and training (including unpaid internship); compulsory military; engaged with household chores and looking after children or incapacitated adults in the family; 
seasonal worker; other); or 3) working full time (reference). We create a dummy variable indicating whether the household owns at least one car for personal use as a measure of household wealth. Car ownership is expensive in Turkey, particularly for low- and middle-income households and is therefore an important control variable. It should be noted that data on wealth is not collected this dataset and presents a limitation in our analyses.

The demographic variables that we measure include: householder's age; dummy variables gauging whether the household is headed by a male, by a married couple, and has children under 18 years of age; and the number of years that the household has spent in the unit. We also control for the nature of the housing unit by using the following dummy variables -1 ) detached (reference); 2) duplex; or 3) in an apartment building.

To fulfill our research objectives, we first conduct descriptive analyses examining the nature of the income-group disparities in housing outcomes, overall, and for owner occupiers. Second, we examine income-group differences in socioeconomic characteristics, demographic factors and other residential characteristics that we have just discussed for all households. For our multivariate analyses, we estimate logistic and linear regression models (i.e., OLS) predicting our housing outcomes in order to determine whether the incomegroup disparities in housing outcomes that emerge in our descriptive analyses are attenuated with the inclusion of relevant control variables, overall and for owner occupiers. We characterize the nature of income-group disparities that 
remain in housing outcomes based upon our odds ratios and OLS regression coefficients.

The main assumptions underlying the linear regression models are met. The one exception was the model for housing value. The variance of the residuals slightly deviated from the homogeneity assumption. To counter this slight misspecification, we applied a variance stabilization transformation. We took the log of housing value and re-estimated the model. The problem was fixed as the estimated variance of the residuals was constant across predicted values. The statistical significance of the regression coefficients of this new model (available upon request from the authors) was very similar to our original model that did not take the log of housing value, and for ease of interpretation, we report the original model.

\section{Results}

Before discussing the results that fulfill our research objectives, it is first necessary to provide an overview of contemporary housing characteristics in urban Turkey as well as other characteristics of the data that we use in our subsequent analyses. Table 1 provides us with descriptive information about housing outcomes, and the socioeconomic, demographic, and other housing-unit characteristics of households in urban Turkey in 2012.

<TABLE 1 ABOUT HERE> 
Table 1 reveals that within urban Turkey, nearly $51 \%$ of households live in owner-occupied housing or are owner occupiers. The average size of dwellings in square meters is about 106 , and more than one quarter $(26.29 \%)$ of homes were built within the last 12 years. The average number of rooms in the homes was 3.53. The bottom of Table 1 reports that the majority of housing units $73.03 \%$-- are located in apartment buildings; only $17 \%$ are located in detached housing. Columns 2 and 3 of Table 1 reveal that owner occupiers reside in larger and newer homes than renter occupiers, and owner occupiers are somewhat less likely to live in apartment buildings and slightly more likely to live in detached housing than renter occupiers. The average housing value of owner occupiers was $116,305(\mathrm{TL})$. Taken together, these results suggest that the quality of owner-occupied housing is better in terms of the size, recency, and nature of the housing stock (i.e., in apartment buildings or not) than the housing of renter occupiers, which is in contrast to earlier research done in Ankara (Sarioglu-Erdogdu 2015).

Column 1 of Table 1 also reports the socioeconomic and demographic characteristics of the overall sample of households in urban Turkey. Nearly half the sample has a primary school education or less, which is consistent with data reported for Turkey as a whole (Turkish Statistical Institute 2019). The majority of the sample is comprised of full-time employees (67.45\%), yet only $37.81 \%$ owns a car for personal use. The average age of the sample is 45.68 years, and the large majority are married households with a male householder. Nearly $61 \%$ 
of households have children under 18 years of age. And households have lived in their unit for an average of 9.69 years.

Comparing the socioeconomic and demographic characteristics between Columns 2 and 3 for households in owner- and renter-occupied housing reveals a few notable differences. Those in owner-occupied housing are less educated and less likely to be full-time workers than those in rental-occupied housing. However, owner-occupiers are more likely to have cars for personal use than rental occupiers. It appears that those living in owner-occupied housing are more likely to be retired, to be older, and are less likely to have children under 18 years of age than those living in rental-occupied housing. The nature of the retirement process appears to be enabling households to purchase and reside in owner-occupied housing later in their lives.

How do housing outcomes vary across income groups? Table 2 presents mean housing outcomes across seven income groups and compares the means each of the lowest and highest three groups to the mean of the middle-income group ( $40^{\text {th }}$ to $60^{\text {th }}$ percentile) for households. These results show that relative to the middle-income group, lower-income groups generally have significantly poorer housing outcomes, and higher-income groups have significantly better housing outcomes. For example, in evaluating the rate of households living in owner-occupied housing, Table 2 shows that nearly $29 \%$ of households in the 0 to $10^{\text {th }}$ income percentile group are owner occupiers, relative to $50.5 \%$ of the middle-income group and nearly $68 \%$ of households in the $90^{\text {th }}$ to $100^{\text {th }}$ percentile 
group. With respect to housing unit size, a similar pattern emerges. The average square meters of the lowest income group is 88.8 and it increases to 103.55 for the middle-income group and to just under 140 square meters for the upper-income group. Turning to our data on the recent construction of housing units, among all households in urban Turkey, $14.69 \%$ of those in the 0 to $10^{\text {th }}$ percentile group live in homes built within the past 12 years, compared to $24.50 \%$ of those in the middle-income group. Among the most affluent income group, $39.67 \%$ live in housing constructed within the past 12 years. The pattern in the differences in the recency of when the homes were built between middle-income households and other groups is similar when examining the data just among owner occupiers.

\section{<TABLE 2 ABOUT HERE>}

Among owner occupiers, however, the income-based disparities in unit size are somewhat less pronounced. Table 2 shows that owner-occupier households in the $20^{\text {th }}$ to $40^{\text {th }}$ percentile reside in homes that are of equivalent sizes to those in the middle-income group. Those in the $60^{\text {th }}$ to $80^{\text {th }}$ percentile group have significantly larger homes than those in the middle-income group, but the magnitude of the disparity is only about three square meters, which is smaller than that among all households. Likewise, the disparity in housing unit size between owner-occupier households in the $10^{\text {th }}$ to $20^{\text {th }}$ percentile is significantly smaller than that of middle-income households, but the difference is only about five square meters. However, significantly disparities exist between middle- 
income households and those at the extremes, in the 0 to $10^{\text {th }}, 80^{\text {th }}$ to $90^{\text {th }}$, and $90^{\text {th }}$ to $100^{\text {th }}$ percentiles.

Table 2 reports one additional housing outcome just for owner occupiers, their average housing value within income groups. It is notable that the difference in average values between the most affluent and middle-income groups is much larger than that between the lowest- and middle-income groups. More specifically, the difference between the lowest- and middle-income groups is $38,307 \mathrm{TL}$, but the difference between the most affluent and middle-income groups is $210,942 \mathrm{TL}$. Moreover, there is a significantly higher average housing value among the most affluent group as compared to households in the $80^{\text {th }}$ to $90^{\text {th }}$ percentile group. More specifically, the most affluent group's average housing value being 2.2 times the size of that of the second highest income group.

Given that affluent households fare significantly better in terms of their residential circumstances than middle-income households, the question to which we now turn is whether income-group differences exist in other socioeconomic characteristics, demographic factors and other related residential characteristics that could explain some or all of these income-based disparities in housing outcomes. Table 3 presents the socioeconomic, demographic, and housing unit characteristics by income level in urban Turkey, fulfilling the second objective of our paper. For brevity, we highlight the key findings. The top part of the table highlights the significant differences that emerge in terms of education levels 
across the income groups. The majority of those in the lowest income group $78.27 \%$-- have a primary school education or less, which is significantly greater than the rate of $50.88 \%$ of those in the middle-income group. In contrast, $16.21 \%$ of those in the most affluent group have achieved such a low level of education. Only $2.5 \%$ of the lowest income group have attained at least a college education, a rate significantly lower than the rate of $11.28 \%$ of the middle-income group. Just over $59 \%$ of the highest-income households have achieved such a high level of educational attainment, which is also significantly higher than the middle-income group rate. The results for an additional measure of socioeconomic status indicative of wealth - car ownership - are notable. While only $7.94 \%$ of the lowest-income households own a car for personal use, the rate jumps to $36.63 \%$ for middle-income households and $75.88 \%$ among the most affluent.

\section{<TABLE 3 ABOUT HERE>}

Shifting to an examination of the demographic characteristics across income groups, Table 3 shows that income-group differences for the variables gauging the prevalence of households with a male householder and the percent married reveal little variation in Turkey. The large majority of households have male householders and there is little variation across income groups. Likewise, a large majority of households are comprised of married couples, and the results vary little by income group. The nature of the housing unit, however, varies by income group. Lower-income households are significantly more likely than the 
middle-income group to live in detached and duplex dwellings, and more affluent households are significantly more likely to live in apartment buildings than the middle-income group. It is likely that the trends for lower-income households reflect their residence in squatter housing or gecekondus.

We now turn to our final analytical objective and assess disparities in housing outcomes after controlling for the socioeconomic, demographic, and residential variables. Table 4 presents the results of our logistic and OLS regression models of housing outcomes by income groups among all households in urban Turkey as well as just among owner-occupier households. Models 2, 3, and 6 are generated from OLS regression models, and we report the coefficients, significance, and standard errors in the tables. For our other three models $(1,4$, and 5), we present the odds ratios and standard errors; we denote the significance level of the coefficients (not shown) next to the standard errors.

\section{<TABLE 4 ABOUT HERE>}

Table 4 reveals that the advantageous housing outcomes of the higherincome groups, particularly those in the $80^{\text {th }}$ to $90^{\text {th }}$ and $90^{\text {th }}$ to $100^{\text {th }}$ percentile groups, relative to the respective middle-income groups, remained significant even after controlling for important socioeconomic, demographic, and housingunit characteristics. The one variable on which the differences were not as pronounced was for the indicator gauging whether the home was built within the last 12 years. At the same time, lower-income groups are generally less likely than middle-income households to be owner occupiers and live in larger and 
newer housing, although some of the differences attenuated with the inclusion of control variables, particularly in the models focused only on owner occupiers. Affluent owner occupiers are significantly more likely than middle-income owner occupiers to have higher housing values, even controlling for relevant factors. We discuss all of these results in more detail below.

With respect to living in owner-occupied housing, model 1 in Table 4 reveals the odds for the lowest-income group to be .324 times the odds of those in the middle-income group, controlling for relevant variables. At the upper-end of the income distribution, the odds of living in owner-occupied housing among the most affluent group are 2.439 times the odds of the middle-income group. All of the differences, relative to the middle-income group remain statistically significant after introducing control variables into the models. Perhaps there must be other factors affecting residence in owner-occupied housing that are not considered here, like access to mortgages or financial credit to purchase homes.

With respect to housing unit size, Table 4 reveals that higher-income groups remain significantly more likely than their middle-income counterparts to live in larger homes, as gauged by the unit's average square meters, controlling for other relevant factors. Model 2 of Table 4 reveals that for all but one of the income-group differences in housing unit size remain, relative to the middleincome group (compared to the differences in Table 1), suggesting that the control variables do not work as effectively in attenuating the income-group disparities in housing outcomes. However, the results for owner occupiers in 
column 3 reveal that only three of the income groups, at the extremes, continue to have significant disparities in unit size with middle-income households.

Owner-occupier households in the $80^{\text {th }}$ to $90^{\text {th }}$ and $90^{\text {th }}$ to $100^{\text {th }}$ percentile income groups have units that are 10.4 and 38.7 square meters larger, on average, than middle-income households, controlling for relevant factors. Households in the lowest income decile have units that are 13.8 square meters smaller than those in the middle-income group. The other income groups do not display significant differences in unit size from middle-income households.

When it comes to examining income-group differences as far as the age of housing is concerned, how do middle-income households fare relative to others? Consistent with the descriptive results in Table 2, model 4 of Table 4 reveals that the top three income groups are significantly more likely than middle-income households to live in housing built within the past 12 years, controlling for other factors, although the level of significance declined. Among owner occupiers, column 5 shows similar results, although the difference in recency of the unit is not significant between the most affluent households in the $90^{\text {th }}$ to $100^{\text {th }}$ percentile and middle-income households.

With respect to the other end of the income distribution, there is no difference in the age of homes between those in the $20^{\text {th }}$ to $40^{\text {th }}$ percentile group and the middle-income group for all households (column 4) and among owner occupiers (column 5), controlling for other factors, which mirrors the pattern of results found in Table 2. Columns 4 and 5 in Table 4 reveal that the difference in 
percent in housing built in the past 12 years between those in the lowest- and middle-income groups is not significant. Moreover, among owner occupiers (column 5), the results show that the difference in recency of the unit is not significant between households in the $10^{\text {th }}$ to $20^{\text {th }}$ percentile and middle-income households.

The final housing variable that we analyze across income groups, specifically for owner occupiers, is housing value. As was the case in the descriptive analyses in Table 2, the highest-income group has average housing values that are extraordinarily higher than their middle-income counterparts, and the jump in difference between the $80^{\text {th }}$ and $90^{\text {th }}$ and $90^{\text {th }}$ to $100^{\text {th }}$ percentile groups is very large. Column 6 of Table 4 reveals that households in the $90^{\text {th }}$ to $100^{\text {th }}$ percentile group have homes that are valued on average $129,027 \mathrm{TL}$ more than households in the middle-income group; the difference in average housing value is $20,511 \mathrm{TL}$ between households in the $80^{\text {th }}$ to $90^{\text {th }}$ and middle percentile income groups. Column 6 of Table 4 reveals that controlling for socioeconomic, demographic, and housing-unit variables, all the upper-income groups have significantly higher housing values than the middle-income group.

Like the descriptive analysis in Table 2, the lowest-income groups have significantly lower average housing values than their respective middle-income counterparts, controlling for other factors (column 6 of Table 4). Also similar is that the magnitude of the differences, relative to the middle-income group, is much smaller than the size of the differences between the most affluent income 
group and the middle-income group. Table 4 shows that the homes of the lowest percentile income group are valued on average $22,205 T L$ less than homes of the middle-income group. In contrast to the descriptive results in Table 2, the difference in average housing values between the $20^{\text {th }}$ and $40^{\text {th }}$ percentile group and the middle-income group is not significant (column 6 of Table 4).

How do the socioeconomic, demographic, and residential characteristics used as control variables affect the housing outcomes that we analyzed in Table 2? For the sake of brevity, we highlight the main results. With respect to socioeconomic factors, we find that education level is consistently related to housing outcomes in Turkey, but some results are not consistent with conventional expectations. More specifically, those with less education are significantly more likely than those with at least a college education to be owner occupiers and to live in housing units built within the last 12 years. In Turkey, retirees are significantly more likely to live in owner-occupied homes than fulltime workers; moreover, among all households (column 2), those in the other labor force status live in homes that are about 3.3 square meters larger than those who work full time. However, labor force status is not significantly related to housing stock age and the value of homes for owner occupiers. In Turkey, car ownership is a consistently significant predictor of housing outcomes, raising the odds of owning a home and living in a larger and newer home. However, it is negatively related to housing value. 
Table 4 reveals that demographic variables also influence housing outcomes. Age is positively related to the odds of living in an owner-occupied home, and older households tend to live in larger and older homes. Married households are more likely than non-married households to be owner occupiers. The presence of children is associated with residence in larger and newer homes, but among owner occupiers, it is associated with lower average housing values. The number of years the household has been in the unit is positively associated with the odds of living in owner-occupied housing; however, the number of years in the unit is negatively associated with unit size, controlling for other relevant factors. There is no impact of housing type on living in owneroccupied housing, but those in apartment buildings live in smaller and newer units than those in detached units.

\section{Discussion and Conclusions}

The primary goal of this paper was to examine the nature of income-based disparities in housing outcomes in Turkey in order to see where middle-income households fall, particularly relative to affluent households. Given the significant growth in newly constructed housing, increase in the middle-class segment of the population, and increasing inequality in wealth in Turkish society (Ceritoglu 2019; The World Bank 2014; Torul and Oztunali 2018; Turel and Koc 2015), it is imperative to understand the housing attainment of middle-income households. To fulfill this main goal, the analysis focused on completing three objectives. 
First, we documented and compared income-group disparities in housing outcomes for households. We found that affluent households are significantly more likely than middle-income households to be owner occupiers, and among all households and owner-occupier households, affluent households are more likely than middle-income households to live in larger homes and more recently built homes. Among owner occupiers, the average housing values for higherincome groups are significantly higher than the middle-income group, which is consistent with Dwyer's research in the U.S. $(2008,2009)$. Of particular note is that for the average size of homes and the average housing value, there is a significant increase in these values between households in the $80^{\text {th }}$ to $90^{\text {th }}$ and $90^{\text {th }}$ to $100^{\text {th }}$ percentile income groups, relative to middle-income households, revealing that extremely affluent households have significantly better homes even than other affluent groups. In general, lower-income households have significantly poorer housing outcomes than middle-income households, among all households and owner-occupier households.

Our second objective was to document income-group differences in socioeconomic, demographic, and other residential characteristics that might affect the differences in housing outcomes. We found that education varied greatly by income groups, consistent with the findings from the 2011 Turkish census (Turkish Statistical Institute 2011). Car ownership also differed significantly across income groups, with those in the higher-income groups being more likely than middle-income group households to own cars for personal use. 
Demographic factors like the share of households with a male householder and the percent married did not vary greatly in magnitude, however.

Did the differences in these characteristics impact the income-group disparities in housing outcomes? Fulfilling our third objective, the results from our multivariate analyses revealed that for the most part, disparities in housing outcomes between the affluent and middle-income households remained, after including relevant variables. One exception was for the outcome gauging whether the home was built within the last 12 years. The disparities between affluent and middle-income households were less pronounced, particularly among owner occupiers, controlling for socioeconomic and demographic factors. Another exception was for households in the $60^{\text {th }}$ to $80^{\text {th }}$ percentile; among all households and owner occupiers, differences in the size of the unit between these households and middle-income households became insignificant. For the outcome, housing value, however, affluent owner occupiers, particularly those in the top two income groups, resided in homes of significantly higher value than middle-income households.

With respect to differences between middle- and lower-income households, the multivariate analyses revealed that, in several instances, the differences in housing outcomes between lower- and middle-income households were not significant. Among owner occupiers and relative to middle-income households, households in the $10^{\text {th }}$ to $20^{\text {th }}$ and $20^{\text {th }}$ to $30^{\text {th }}$ percentile groups resided in units of equivalent size and were equally likely to live in units built in 
the last 12 years, controlling for other factors. In addition, among all households and owner occupiers, disparities in the unit being built within the past 12 years became insignificant between the lowest- and middle-income households. Significant disparities remained between lower- and middle-income households in terms of living in owner-occupied units, unit size (among all households), and housing value, with those in middle-income households achieving better housing than their lower-income counterparts.

Taken together, we make three connections between our findings and the features of the Turkish housing market discussed earlier in the paper. First, the significant expansion in newly constructed housing that has taken place in Turkey, which in part was facilitated by owner-occupied housing produced by the HDA (Coskun 2016; Ozdemir 2011; Sari and Khurami 2018; Sarioglu-Erdogdu 2014; Turel and Koc 2015), has had a positive impact on the use value of Turkish households, particularly among owner occupiers. Few disparities exist in unit size between middle-income owners and those in the $10^{\text {th }}$ to $20^{\text {th }}, 20^{\text {th }}$ to $40^{\text {th }}$, and $60^{\text {th }}$ to $80^{\text {th }}$ percentiles. In addition, few pronounced disparities exist between middle-income households and other households in living in housing units built within the past 12 years. Particularly intriguing is the fact that among owner occupiers, middle-income households are equally likely as the most affluent households to live in units built within the past 12 years. Thus, the significant increase in newly constructed housing has provided households 
across the income spectrum, and particularly for owner occupiers, with the opportunity to live in recently built housing.

Second, the 2007 Mortgage Law does not appear to be reducing differences in living in owner-occupied housing for middle- and lower-income households, relative to affluent households. Our results reveal that significant income-based disparities exist in access to living in owner-occupied housing. We also find that those with less education are more likely than those with at least a college education to own their homes and that those who are retired are more likely than those who are working full-time to own their homes. These counterintuitive findings suggest that more research should be done to examine contemporary home-buying patterns in Turkey. In Turkey, the volume of mortgages is much smaller than in other developed countries like the U.S. (Coskun 2016). In 2017, of all home sales, $34 \%$ were financed by mortgages (Sari and Khurmani 2018). Future research should examine the demographics of the households using this relatively new financing system so that more households can benefit.

Third, our results suggest that despite the fact that many households are experiencing access to newer housing within Turkey, as shown by the absence of significant differences in the recency of their homes, and thereby experiencing enhanced use value of their homes, the exchange value of housing, as demonstrated by the results for housing value, are of prominent concern to the most affluent households in Turkish society. The fact the income-based housing 
disparities were much larger at the upper-most end of the income distribution than at the lower end of the distribution likely reflects the power of the most affluent households to influence housing development and the maintenance of their high levels of wealth (Genis 2007; Guzey 2014).

Among owner occupiers, our findings reveal fewer disparities between lower- and middle-income households with respect to unit size and living in units built within the last 12 years, especially compared to the differences between middle-income and the upper-two most affluent income households. These findings and those revealing significantly large disparities in housing value between middle-income households and the two most affluent groups likely suggest that the most affluent groups in urban Turkish society are distancing themselves from middle- and lower-income households and predominantly residing in exclusive communities. This is consistent with the research done on residential segregation in Turkey, which uses data from 2000 and earlier, and shows that high-status groups are the most separated from low-status groups, with middle-status groups residing between the two other groups (Atac 2017; Pinarcioglu and Isik 2009). It is also consistent with findings regarding incomebased residential segregation in the U.S. that have shown that affluent households and not the poorest households are the most likely to distance themselves from other households in metropolitan America (Reardon and Bischoff 2011). 
No doubt there are limitations to our study that should be acknowledged. Our study is based upon data from one point in time, and therefore we are unable to examine any causal relationships. Thus, we cannot pinpoint exactly why the income-based, housing disparities exist. In addition, without measures of wealth, we do not know whether income differences would disappear in predicting housing outcomes. A final limitation with this paper is that it only studies income-based disparities in housing outcomes in just one country. While our results are similar to findings from U.S. based research (Dwyer 2008, 2009), expanding the examination of such differences to a larger number of countries would be beneficial in assessing whether middle-income households are disadvantaged in a broader range of countries, particularly at varying levels of income and wealth inequality and where the middle-income segment of the population is expanding (Kharas 2017).

Our study should serve as a point of departure for additional research, and moving forward, it is imperative for researchers to understand the residential mobility dynamics that underlie the income-based disparities in housing outcomes uncovered here. A particularly fruitful avenue of research would be to focus on the process undertaken by lower-income, middle-income, and affluent households in deciding whether to move, choosing a residential destination, and acquiring resources via mortgage loans or other methods to finance their mobility. If remained unchecked, the income-based disparities in housing presented in this analysis will facilitate future income and wealth disparities in 
urban Turkey, particularly because housing is inextricably linked to household wealth. These disparities will have implications for the well-being of the middleand lower-income households within Turkey, and future levels of income and wealth inequality could become even greater. 


\section{References}

Atac, Ela. 2017. "Turkish-Style Segregation: Socio-Economic Divisions in Seven Metropolitan Areas." Asian Journal of Social Science 45: 235-270.

Ceritoglu, Evren. 2019. “Homeownership, Housing Demand, and Household Wealth Distribution in Turkey." Emerging Markets Finance and Trade https://www.tandfonline.com/doi/full/10.1080/1540496X.2018.1555461

Coskun, Yener. 2016. "Housing Finance in Turkey over the Last 25 Years: Good, Bad, or Ugly?" Pp. 393-412 in Milestones in European Housing Finance, edited by Jens Lunde and Christine Whitehead. Chichester, West Sussex, UK: Wiley/Blackwell.

Dwyer, Rachel E. 2008. "Cohort Succession in theU.S.Housing Market: New Houses, the Baby Boom, and Income Stratification." Population Research and Policy Review 27: 161-181.

Dwyer, Rachel E. 2009. "The McMansionization of America? Income Stratification and the Standard of Living in Housing, 1960-2000." Research in Social Stratification and Mobility 27: 285-300.

Erkip, Feyzan. 2010. "Community and Neighborhood Relations in Ankara: An Urban-Suburban Contrast." Cities 27:96-102.

Genis, Serife. 2007. "Producing Elite Localities: The Rise of Gated Communities in Istanbul." Urban Studies 44(4):771-798. 
Guzey, Ozlem. 2014. "Neoliberal Urbanism Restructuring the City of Ankara: Gated Communities as a New Life Style in a Suburban Settlement." Cities 36:93-106.

HDA (Housing Development Administration). 2019. Housing Development Administration webpage on "Housing Programs." Accessed May 25, 2019. (https://www.toki.gov.tr/en/housing-programs.html)

Kharas, Homi. 2017. "The Unprecedented Expansion of the Global Middle Class: An Update." Global Economy \& Development. Working Paper 100. Washington, DC: The Brookings Institution.

Kurtulus, Hatice. 2011. "Gated Communities as a Representation of New Upper and Middle Classes in Istanbul." I.U. Siyasal Bilgiler Fakultesi Dergisi $44: 49-65$.

Logan, John R. and Harvey Molotch. 1987. Urban Fortunes: The Political Economy of Place. CA: University of California Press.

OECD. 2016. Income Inequality Update: Income Inequality Remains High in the Face of Weak Recovery. Centre for Opportunity and Equality.

OECD. 2019. Under Pressure: The Squeezed Middle Class. Paris: OECD Publishing. https://doi.org/10.1787/689afed1-en.

Ozdemir, Dilek. 2011. "The Role of the Public Sector in the Provision of Housing Supply in Turkey, 1950-2009." International Journal of Urban and Regional Research 35(6):1099-1117. 
Palancioglu, Haci Mustafa and Mehmet Cete. 2014. "The Turkish Way of Housing Supply and Finance for Low- and Middle-Income People." Land Use Policy 39(2014):127-134.

Pew Research Center. 2015. "The American Middle Class is Losing Ground: No Longer the Majority and Falling Behind Financially." Washington, DC: December.

Pinarcioglu, M. Melih and Oguz Isik. 2009. "Segregation in Istanbul: Patterns and Processes." Journal of Economic and Social Geography (TESG) 100(4): 469-484.

Reardon, Sean F. and Kendra Bischoff. 2011. "Income Inequality and Income Segregation." American Journal of Sociology 116(4):1092-1153.

Republic of Turkey Prime Ministry. 2013. Investment Support and Promotion Agency. "Economic Outlook" webpage. Accessed July 21, 2013 (http://www.invest.gov.tr/enus/turkey/factsandfigures/pages/economy.aspx\#PageTop).

Sari, O. Burcu Ozdemir and Esma Aksoy Khurami. 2018. "Housing Affordability Trends and Challenges in the Turkish Case." Journal of Housing and the Built Environment https://doi.org/10.1007/s10901-018-9617-2

Sarioglu-Erdogdu, G. Pelin. 2010a. "A Comparative Analysis of Entry to Home Ownership Profiles: Turkey and the Netherlands." METU JFA 27(2):95124. 
Sarioglu-Erdogdu, G. Pelin. 2010b. Entry to Home Ownership: A Comparison between Turkey and the Netherlands. Dissertation manuscript.

Sarioglu-Erdogdu, G. Pelin. 2014. "Housing Development and Policy Change: What Has Changed in Turkey in the Last Decade in the Owner-Occupied and Rented Sectors?" Journal of Housing and the Built Environment 29:155-175.

Sarioglu-Erdogdu, G. Pelin. 2015. "Well-being of renters in Ankara: An empirical Analysis." Habitat International 48:30-37.

Torul, Orhan and Oguz Oztunali. 2018. "On Income and Wealth Inequality in Turkey." Central Bank Review 18:95-106.

Turel, Ali and Hulya Koc. 2015. "Housing Production under Less-Regulated Market Conditions in Turkey." Journal of Housing and the Built Environment 30:53-68.

Turkish Statistical Institute. 2011. Population and Housing Census, 2011. Ankara, Turkey.

Turkish Statistical Institute. 2012. Income and Living Conditions Survey, 2012. Ankara, Turkey.

Turkish Statistical Institute. 2016. Tables from Short Term Business Statistics on Occupancy Permits. Retrieved June 7, 2016 (http://www.turkstat.gov.tr). Turkish Statistical Institute. 2019. Table of the Distribution of Population by the Education Completed, 2008-2018. Retrieved November 1, 2019 (http://www.turkstat.gov.tr). 
Ucar, Baris. 2015. "The Usability of Asset Index as an Indicator of Household Economic Status in Turkey: Comparison with Expenditure and Income Data." Social Indicators Research 121:745-760.

The World Bank. 2014. Turkey's Transitions: Integration, Inclusion, Institutions. Report No. 90509-TR. Washington, DC. Retrieved October 20, 2015. The World Bank Data. 2018. "The World Bank in Turkey - Country Snapshot." The World Bank Group. Retrieved September 15, 2018 (http://pubdocs.worldbank.org/en/372961524127066297/TurkeySnapshot-Spring2018.pdf).

The Work Bank Data. 2020a. "Unemployment, male (\% of male labor force) (national estimate) - Turkey." The World Bank. Retrieved January 3, 2020 (https://data.worldbank.org/indicator/SL.UEM.TOTL.MA.NE.ZS?locations= $\underline{\mathrm{TR}}$.

The World Bank Data. 2020b. "Consumer price index $(2010=100)-$ Turkey." The World Bank. Retrieved January 3, 2020 (https://data.worldbank.org/indicator/FP.CPI.TOTL?locations=TR).

The World Bank Group. 2018. Turkey Economic Monitor, December 2018:

Steadying the Ship. Washington, DC. Retrieved December 31, 2019. 
Table 1. Housing Outcomes, Socioeconomic, Demographic, and Other Housing Unit Characteristics in Urban Turkey (2012) (weighted)

\begin{tabular}{|c|c|c|c|}
\hline & $\begin{array}{c}\text { All } \\
\text { Households }\end{array}$ & $\begin{array}{c}\text { Owner } \\
\text { Occupiers }\end{array}$ & $\begin{array}{c}\text { Renter } \\
\text { Occupiers }\end{array}$ \\
\hline Variables & (1) & $(2)$ & $(3)$ \\
\hline \multicolumn{4}{|l|}{ Housing Outcomes } \\
\hline Percent owner-occupiers & 50.49 & NA & NA \\
\hline Unit square meters (USM) (mean) & 106.08 & $110.32^{* * *}$ & 101.76 \\
\hline Percent in home built within the last 12 years & 26.29 & $30.35^{\star * *}$ & 22.15 \\
\hline Housing value (in TL) & NA & 116305.00 & NA \\
\hline Number of rooms in the home (mean) & 3.53 & $3.64^{* * *}$ & 3.43 \\
\hline \multicolumn{4}{|l|}{ Socioeconomic \& Demographic Characteristics } \\
\hline \multicolumn{4}{|l|}{ Education (percent) } \\
\hline \multirow{2}{*}{$\begin{array}{l}\text { Primary school completed or less education } \\
\text { Secondary, high school, or vocational school degree }\end{array}$} & 48.66 & $52.95^{\star * *}$ & 44.28 \\
\hline & 32.45 & $28.82^{* * *}$ & 36.14 \\
\hline At least some college education & 18.90 & 18.23 & 19.58 \\
\hline \multicolumn{4}{|l|}{ Employment status (percent) } \\
\hline Full-time employee & 67.45 & $56.60^{* * *}$ & 78.50 \\
\hline Retired/disabled/unable to work & 16.96 & $26.57^{* * *}$ & 7.15 \\
\hline Other status (e.g., looking for a job, student, inactive) & 15.60 & $16.83^{* *}$ & 14.35 \\
\hline Percent owns a car for personal use & 37.81 & $44.61^{* * *}$ & 30.88 \\
\hline Age (mean) & 45.68 & $50.96^{* * *}$ & 40.29 \\
\hline \multicolumn{4}{|l|}{ Percent: } \\
\hline Households with a male householder & 87.11 & $86.20^{*}$ & 88.03 \\
\hline Married households & 84.72 & 85.08 & 84.35 \\
\hline With children under 18 years of age & 60.58 & $52.56^{* * *}$ & 68.77 \\
\hline Number of years in the unit (mean) & 9.69 & $13.04^{* * *}$ & 6.28 \\
\hline \multicolumn{4}{|l|}{ Housing unit characteristics/location } \\
\hline \multicolumn{4}{|l|}{ Nature of unit (percent) } \\
\hline Detached & 17.04 & $18.72^{* * *}$ & 15.32 \\
\hline Duplex & 9.93 & 10.30 & 9.56 \\
\hline In apartment building & 73.03 & $70.99^{* * *}$ & 75.12 \\
\hline $\mathrm{N}$ & 6870 & 3629 & 3241 \\
\hline
\end{tabular}


Table 2. Housing Outcomes by Income Level in Urban Turkey (2012) (weighted)

\begin{tabular}{|c|c|c|c|c|c|c|c|}
\hline & \multicolumn{7}{|c|}{ Income Percentile Group } \\
\hline & 0 to 10 & 10 to $20^{1}$ & 20 to 40 & 40 to 60 & 60 to 80 & 80 to 90 & 90 to 100 \\
\hline Variables & (1) & (2) & (3) & (4) & (5) & (6) & (7) \\
\hline Percent owner occupiers & $28.71^{* * *}$ & $42.44^{* *}$ & $42.45^{\star * *}$ & 50.50 & $58.99^{* * *}$ & $62.09^{* * *}$ & $67.76^{* * *}$ \\
\hline Unit square meters (USM) (mean) & $88.80^{* * *}$ & $94.44^{* * *}$ & $99.88^{* * *}$ & 103.55 & $107.74^{* * *}$ & $115.51^{* \star *}$ & $139.67^{* * *}$ \\
\hline Percent in home built within the last 12 years & $14.69^{* * *}$ & $13.51^{* * *}$ & 23.34 & 24.50 & $31.66^{* * *}$ & $35.97^{* * *}$ & $39.67^{* * *}$ \\
\hline $\mathrm{N}$ & 687 & 686 & 1375 & 1373 & 1374 & 687 & 688 \\
\hline \multicolumn{8}{|l|}{ Among owner occupiers: } \\
\hline Unit square meters (USM) (mean) & $90.80^{* * *}$ & $101.35^{* *}$ & 104.05 & 106.09 & $109.25^{*}$ & $120.22^{\star \star *}$ & $151.98^{* * *}$ \\
\hline Percent in home built within the last 12 years & $17.29^{* * *}$ & $20.18^{* *}$ & 25.51 & 29.32 & $37.87^{* *}$ & $40.43^{* * *}$ & $40.17^{* * *}$ \\
\hline Housing value (in TL) (mean) & $55,971^{* * *}$ & $76,812^{* * *}$ & $87,112^{* *}$ & 94,278 & $110,832^{* * *}$ & $140,194^{* * *}$ & $305,220^{* * *}$ \\
\hline $\mathrm{N}$ & 363 & 363 & 726 & 726 & 726 & 362 & 364 \\
\hline
\end{tabular}

NOTE: reference group is $40^{\text {th }}$ to $60^{\text {th }}$ percentile group; ${ }^{* * *} p<=.001 ;{ }^{* *} p<=.01 ;{ }^{*} p<=.05$

${ }^{1}$ Income percentile categories are mutually exclusive; the groups include those in the lower bound (i.e., with incomes at the $10^{\text {th }}$ percentile) but do not include those at the upper bound (i.e., have incomes just below the threshold at the $20^{\text {th }}$ percentile). 
Table 3. Socioeconomic, Demographic, and Housing Unit Characteristics by Income Level in Urban Turkey (2012) (all households, weighted)

\begin{tabular}{|c|c|c|c|c|c|c|c|}
\hline \multirow[b]{3}{*}{ Variables } & \multicolumn{7}{|c|}{ Income Percentile Group } \\
\hline & 0 to 10 & 10 to $20^{1}$ & 20 to 40 & 40 to 60 & 60 to 80 & 80 to 90 & 90 to 100 \\
\hline & (1) & (2) & (3) & (4) & (5) & (6) & (7) \\
\hline \multicolumn{8}{|l|}{$\begin{array}{l}\text { Socioeconomic \& Demographic Characteristics } \\
\text { Education (percent) }\end{array}$} \\
\hline Primary school completed or less education & $78.27^{\star * *}$ & $70.48^{* * *}$ & $56.94^{* *}$ & 50.88 & $37.81^{* * *}$ & $30.41^{* * *}$ & $16.21^{* * *}$ \\
\hline $\begin{array}{l}\text { Secondary, high school, or vocational school } \\
\text { degree }\end{array}$ & $19.23^{* * *}$ & $26.37^{* * *}$ & 36.46 & 37.85 & 37.02 & $31.49^{* *}$ & $24.71^{* * *}$ \\
\hline \multicolumn{7}{|l|}{ Employment status (percent) } & $59.08^{* * *}$ \\
\hline Full-time employee & $51.87^{* * *}$ & $55.52^{* * *}$ & $66.04^{*}$ & 70.78 & 70.46 & 71.87 & $80.61^{* * *}$ \\
\hline Retired/disabled/unable to work & $8.35^{\star * *}$ & 19.26 & 18.14 & 16.94 & $20.18^{*}$ & 17.97 & 13.44 \\
\hline $\begin{array}{l}\text { Other status (e.g., looking for a job, student, } \\
\text { inactive) }\end{array}$ & $39.78^{* * *}$ & $25.22^{* * *}$ & $15.82^{*}$ & 12.28 & $9.36^{*}$ & 10.15 & $5.94^{* * *}$ \\
\hline $\begin{array}{l}\text { Percent owns a car for personal use } \\
\text { Age (mean) }\end{array}$ & $\begin{array}{l}7.94^{\star * *} \\
45.07\end{array}$ & $\begin{array}{l}18.15^{\star * *} \\
46.75\end{array}$ & $\begin{array}{l}24.42^{* * *} \\
44.46^{* *}\end{array}$ & $\begin{array}{l}36.63 \\
45.90\end{array}$ & $\begin{array}{l}46.41^{* * *} \\
46.27\end{array}$ & $\begin{array}{l}61.20^{* * *} \\
45.66\end{array}$ & $\begin{array}{l}75.88^{* * *} \\
46.04\end{array}$ \\
\hline \multicolumn{8}{|l|}{ Percent: } \\
\hline Households with a male householder & $75.76^{\star * *}$ & $81.00^{* * *}$ & 88.42 & 87.14 & $90.63^{* *}$ & $91.92^{* *}$ & 89.97 \\
\hline Married households & $72.81^{* * *}$ & $78.68^{* * *}$ & 85.90 & 85.01 & $88.23^{*}$ & 87.93 & $89.49^{* *}$ \\
\hline With children under 18 years of age & 62.75 & 62.73 & 62.55 & 59.78 & 60.00 & 58.29 & 57.42 \\
\hline Number of years in the unit (mean) & 9.97 & $11.68^{* *}$ & 9.45 & 9.92 & 9.78 & $8.68^{* *}$ & $8.35^{* * *}$ \\
\hline \multicolumn{8}{|l|}{ Housing unit characteristics/location } \\
\hline \multicolumn{8}{|l|}{ Nature of unit (percent) } \\
\hline Detached & $34.66^{* * *}$ & $27.10^{* * *}$ & $20.15^{\star *}$ & 16.17 & $11.16^{* * *}$ & $6.38^{* * *}$ & $7.31^{* * *}$ \\
\hline Duplex & $19.41^{* * *}$ & $16.39^{* * *}$ & 9.17 & 8.64 & 7.48 & $4.98^{* *}$ & 7.98 \\
\hline In apartment building & $45.93^{* * *}$ & $56.52^{* * *}$ & $70.68^{*}$ & 75.19 & $81.36^{* * *}$ & $88.64^{* * *}$ & $84.71^{* * *}$ \\
\hline $\mathrm{N}$ & 687 & 686 & 1375 & 1373 & 1374 & 687 & 688 \\
\hline
\end{tabular}

NOTE: reference group is $40^{\text {th }}$ to $60^{\text {th }}$ percentile group; ${ }^{* * *} p<=.001 ;{ }^{* *} p<=.01 ;{ }^{*} p<=.05$

${ }^{1}$ Income percentile categories are mutually exclusive; the groups include those in the lower bound (i.e., with incomes at the $10^{\text {th }}$ percentile) but do not include those at the upper bound (i.e., have incomes just below the threshold at the $20^{\text {th }}$ percentile). 


\begin{tabular}{|c|c|c|c|c|c|c|}
\hline & All hhs & All hhs & $\begin{array}{c}\text { Owner } \\
\text { Occupiers }\end{array}$ & All hhs & $\begin{array}{c}\text { Owner } \\
\text { Occupiers }\end{array}$ & $\begin{array}{c}\text { Owner } \\
\text { Occupiers }\end{array}$ \\
\hline & $\begin{array}{l}\text { Living in } \\
\text { Owner } \\
\text { Occupied } \\
\text { Housing }\end{array}$ & $\begin{array}{l}\text { Unit Square } \\
\text { Meters } \\
\text { (USM) }\end{array}$ & $\begin{array}{l}\text { Unit Square } \\
\text { Meters } \\
\text { (USM) }\end{array}$ & $\begin{array}{c}\text { Home Built } \\
\text { within last } 12 \\
\text { years }\end{array}$ & $\begin{array}{c}\text { Home Built } \\
\text { within last } \\
12 \text { years }\end{array}$ & $\begin{array}{l}\text { Housing } \\
\text { Value }\end{array}$ \\
\hline Variables & (1) & $(2)$ & (3) & (4) & (5) & (6) \\
\hline \multicolumn{7}{|l|}{ Income Percentile Groups (ref. 40th to 60th group) } \\
\hline 0 to 10 & $\begin{array}{c}0.324 \\
(0.138)^{\star * *}\end{array}$ & $\begin{array}{c}-12.003^{* * *} \\
(1.445)\end{array}$ & $\begin{array}{c}-13.841^{* * *} \\
(2.109)\end{array}$ & $\begin{array}{c}0.772 \\
(0.149)\end{array}$ & $\begin{array}{c}0.789 \\
(0.190)\end{array}$ & $\begin{array}{c}-22204.67^{* * *} \\
(5729.60)\end{array}$ \\
\hline 10 to $20^{1}$ & $\begin{array}{c}0.589 \\
(0.119)^{\star * *}\end{array}$ & $\begin{array}{c}-6.485^{* * *} \\
(1.356)\end{array}$ & $\begin{array}{l}-2.777 \\
(1.882)\end{array}$ & $\begin{array}{c}0.617 \\
(0.142)^{\star \star *}\end{array}$ & $\begin{array}{c}0.761 \\
(0.178)\end{array}$ & $\begin{array}{c}-14387.90^{* * *} \\
(4062.33)\end{array}$ \\
\hline 20 to 40 & $\begin{array}{c}0.724 \\
(0.095)^{\star \star \star}\end{array}$ & $\begin{array}{l}-2.428^{*} \\
(1.040)\end{array}$ & $\begin{array}{l}-1.312 \\
(1.506)\end{array}$ & $\begin{array}{c}1.017 \\
(0.101)\end{array}$ & $\begin{array}{c}0.911 \\
(0.135)\end{array}$ & $\begin{array}{l}-6113.55 \\
(3448.00)\end{array}$ \\
\hline 60 to 80 & $\begin{array}{c}1.416 \\
(0.097)^{\star \star \star}\end{array}$ & $\begin{array}{c}1.569 \\
(1.055)\end{array}$ & $\begin{array}{c}0.672 \\
(1.454)\end{array}$ & $\begin{array}{c}1.214 \\
(0.096)^{*}\end{array}$ & $\begin{array}{c}1.366 \\
(0.129)^{*}\end{array}$ & $\begin{array}{c}11561.85^{\star * *} \\
(3418.43)\end{array}$ \\
\hline 80 to 90 & $\begin{array}{c}1.843 \\
(0.125)^{\star * \star}\end{array}$ & $\begin{array}{l}7.353^{* * *} \\
(1.533)\end{array}$ & $\begin{array}{c}10.429^{\star * *} \\
(2.572)\end{array}$ & $\begin{array}{c}1.262 \\
(0.118)^{*}\end{array}$ & $\begin{array}{c}1.416 \\
(0.157)^{*}\end{array}$ & $\begin{array}{c}20511.15^{\star * *} \\
(6194.90)\end{array}$ \\
\hline 90 to 100 & $\begin{array}{c}2.439 \\
(0.129)^{\star \star *}\end{array}$ & $\begin{array}{c}28.182^{* * *} \\
(2.830)\end{array}$ & $\begin{array}{c}38.729^{* * *} \\
(4.796)\end{array}$ & $\begin{array}{c}1.299 \\
(0.119)^{*}\end{array}$ & $\begin{array}{c}1.345 \\
(0.161)\end{array}$ & $\begin{array}{c}129026.82^{* * *} \\
(14532.87)\end{array}$ \\
\hline \multicolumn{7}{|l|}{ Socioeconomic \& Demographic Characteristics } \\
\hline Primary school completed or less education & $\begin{array}{c}1.595 \\
(0.100)^{\star \star \star}\end{array}$ & $\begin{array}{c}-9.887^{\star * *} \\
(1.548)\end{array}$ & $\begin{array}{c}-9.909^{* \star *} \\
(2.518)\end{array}$ & $\begin{array}{c}0.616 \\
(0.092)^{\star \star \star}\end{array}$ & $\begin{array}{c}0.812 \\
(0.125)\end{array}$ & $\begin{array}{c}-29037.98^{* *} \\
(8938.54)\end{array}$ \\
\hline Secondary, high school, or vocational school degree & $\begin{array}{c}1.218 \\
(0.093)^{*}\end{array}$ & $\begin{array}{c}-4.662^{* \star *} \\
(1.548)\end{array}$ & $\begin{array}{l}-2.932 \\
(2.279)\end{array}$ & $\begin{array}{c}0.650 \\
(0.087)^{\star * \star}\end{array}$ & $\begin{array}{c}0.709 \\
(0.120)^{\star *}\end{array}$ & $\begin{array}{l}-13083.90 \\
(10975.30)\end{array}$ \\
\hline \multicolumn{7}{|l|}{ Employment status (ref. working full-time) } \\
\hline Retired/disabled/unable to work & $\begin{array}{c}1.722 \\
(0.109)^{\star \star \star}\end{array}$ & $\begin{array}{c}0.894 \\
(1.444)\end{array}$ & $\begin{array}{l}-0.352 \\
(1.924)\end{array}$ & $\begin{array}{l}1.075 \\
(0.109)\end{array}$ & $\begin{array}{c}1.083 \\
(0.126)\end{array}$ & $\begin{array}{l}-5515.93 \\
(7876.47)\end{array}$ \\
\hline $\begin{array}{l}\text { Other status (e.g., Part-time work, looking for a job, } \\
\text { military service, student, inactive) }\end{array}$ & $\begin{array}{c}1.228 \\
(0.108)\end{array}$ & $\begin{array}{l}3.271^{*} \\
(1.513)\end{array}$ & $\begin{array}{c}0.654 \\
(2.379)\end{array}$ & $\begin{array}{c}0.992 \\
(0.108)\end{array}$ & $\begin{array}{c}0.995 \\
(0.152)\end{array}$ & $\begin{array}{l}-12116.27 \\
(9210.78)\end{array}$ \\
\hline Owns a car for personal use & $\begin{array}{c}1.379 \\
(0.109)^{\star * *}\end{array}$ & $\begin{array}{l}4.355^{\star * *} \\
(0.945)\end{array}$ & $\begin{array}{l}4.022^{* *} \\
(1.410)\end{array}$ & $\begin{array}{c}1.281 \\
(0.069)^{* * *}\end{array}$ & $\begin{array}{l}1.106 \\
(0.091)\end{array}$ & $\begin{array}{c}-19448.17^{* *} \\
(6038.48)\end{array}$ \\
\hline Age & $\begin{array}{c}1.044 \\
(0.004)^{* * *}\end{array}$ & $\begin{array}{c}0.297^{* * *} \\
(0.046)\end{array}$ & $\begin{array}{c}0.417^{* * *} \\
(0.069)\end{array}$ & $\begin{array}{c}0.969 \\
(0.004)^{* * *}\end{array}$ & $\begin{array}{c}0.962 \\
(0.005)^{\star * \star}\end{array}$ & $\begin{array}{c}402.52 \\
(239.59)\end{array}$ \\
\hline
\end{tabular}

NOTE: Odds ratios and standard errors reported; ${ }^{* *} \mathrm{p}<=.001 ;{ }^{* *} \mathrm{p}<=.01 ;{ }^{*} \mathrm{p}<=.05$

${ }^{1}$ These categories are mutually exclusive; see note under Tables $1 \& 2$. 
Table 4. Logistic \& OLS Regression Models of Housing Outcomes in Urban Turkey, 2012 (weighted)

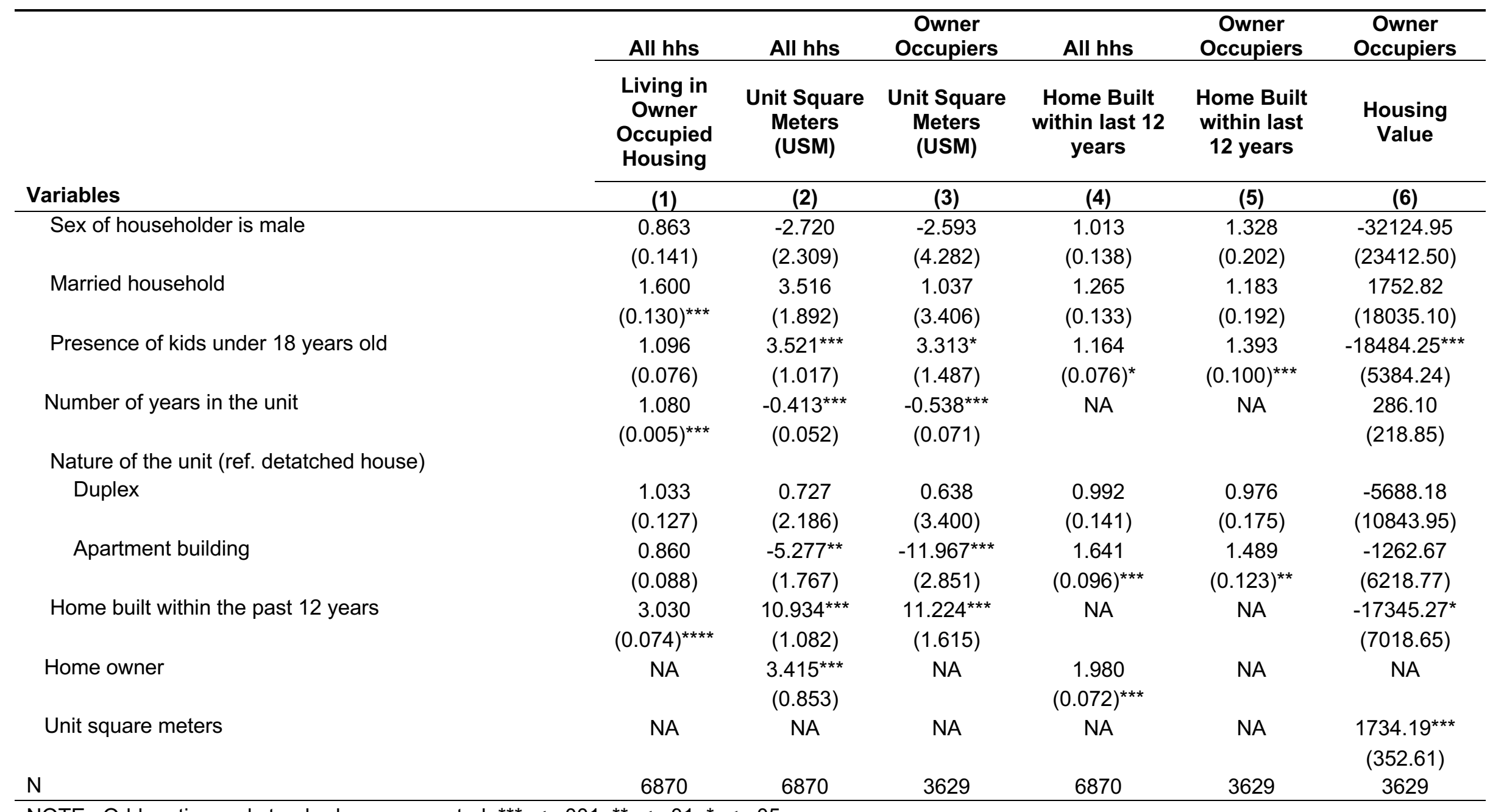

NOTE: Odds ratios and standard errors reported; ${ }^{* * *} \mathrm{p}<=.001 ;{ }^{* *} \mathrm{p}<=.01 ;{ }^{*} \mathrm{p}<=.05$ 